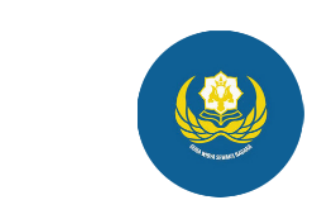

Jurnal Ekonomi dan Bisnis Jagaditha

Volume 7, Nomor 2, 2020, pp. 128-137

EISSN 2579-8162

ISSN 2355-4150

JAGADITHA

https://ejournal.warmadewa.ac.id/index.php/jagaditha

\title{
Green Accounting: An Environmental Pollution Prevention Effort to Support Business Continuity
}

\author{
I Gusti Agung Prama Yoga \& Ida I Dewa Ayu Manik Sastri \\ Universitas Warmadewa, Denpasar, Bali - Indonesia \\ pramayoga13@gmail.com,maniksastri@gmail.com
}

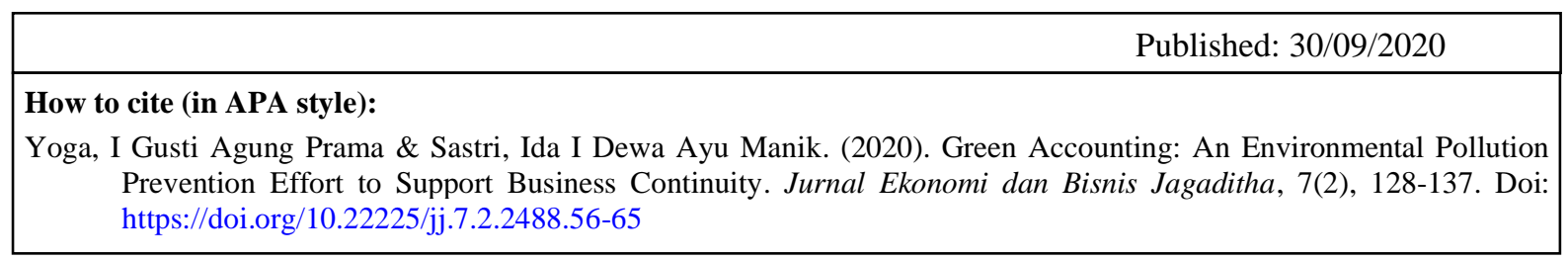

\begin{abstract}
Green accounting has appeared as an accounting era putting forward the environmental factors as the impact of the business sustainability principle that must be maintained by an entity. This study aims to examine the environmental accounting treatment that has been applied by PT Quarzia Batik Baliand to determine the implementation of Green Accounting in supporting the business continuity of PT Quarzia Batik Bali. Business continuity acts as an economic principle, while environmental sustainability represents the social and environmental impacts generated by economic actors. These two aspects must be reconciled as their crucial nature is long-term. This study is design by using the descriptive-interpretive qualitative analysis method, which is a tool to analyse the information and data collected by interpreting the data based on the actor's perspective. Systematically, this data processing and analysis method consists of three concurrent flows of analysis activities, such as data collection through interviews and questionnaires, data reduction, and drawing conclusions. The results showed that PT Quarzia Batik Bali has anticipated the environmental pollution due to dyed waste produced from the garment industry using environmentally-friendly dyes and provides several storage tanks to recycle waste so it remains ready to be disposed of on earth. However, in the financial report the processing cost has not been presented separately as an anticipated cost of environmental pollution.
\end{abstract}

Keywords: Business Continuity; Green accounting

\section{INTRODUCTION}

The continuity of a business needs to serves as the main objective in accounting development, but sometimes business entities at the shortterm business category inadvertently neglect to think back to that the impact on their business operations will interfere with the sustainability of their business in the future. Accounting grows and develops in a society that is also growing, and businesses have found that conventional accounting systems are not sufficient and adequate in line with the increasing complexity of business. The modern economy as it is today has raised various environment-related issues, such as global warming, eco-efficiency, and other industrial activities that have a direct impact on the surrounding environment. Conventional accounting only pays attention to the management and owners of capital (stockholder and bondholder) of the company, while other sectors are often put aside (Burhany, 2011).

The demands for companies are getting bigger and companies must see a new side, namely responsibility to stakeholders, where the company is not only concerned with the interests of management and capital owners, but also employees, consumers, and society. Bebbington (2001) stated that accounting plays a crucial role in managing the relationship 
between companies and the environment. From an accounting point of view, social responsibility and environmental responsibility are unique responsibilities, especially in relation to disclosure and reporting (Andayani \& Riduwan, 2011). Apart from the demands of the community, organised environmental management will basically have implications for the company in the future. The company holds a social responsibility towards the parties outside management and owners of capital. Unfortunately, companies sometimes neglect this responsibility on the grounds that they do not contribute to the survival of the company (Burhany, 2011). This is due to the nonreciprocal relationship between the company and its environment; the transaction between the two does not give rise to a reciprocal presentation. Environmental responsibility has various impacts on company performance. A well-managed company not only pursues economic benefits, but also must have concern for environmental sustainability and the welfare of the surrounding community in order that they can move forward and continue to maintain their business continuity. Such realities can be considered as environmental problems arising more because of the side effects of development.

The various kinds of industrial and technological activities existing today, if not accompanied by a well-organised waste treatment program, will lead to severe environmental pollution. One of the garment industries in Ubud is PT Quarzia Batik Bali. Any polluted environment will, either directly or indirectly, cause environmental damage gradually. Environmental damage when viewed from the occurrence of events can be divided into two: (1) Damage that occurs due to natural changes; (2) Pollution. As it is perceived, environmental preservation plays a crucial role and urgent nature to carry out. A sustainable environment will have a positive impact on the local community. Damage on land and at sea consequently results in an imbalance and uselessness of the environment, and thus the lives of humans and other creatures are disturbed. Business entities managing natural resources for their production have the potential to create environmental damage. Accordingly, companies are required to assume responsibility for stakeholders. When environmental resources are for the company's business interests, the companies need to hold accountability to stakeholders (Abdullah, Muchlis, \& Sari, 2015). Companies must pay attention to the surrounding environment for the business continuity guarantee. To overcome water pollution, preventive efforts can be made, for example by not dumping industrial waste into rivers. The habit of disposing of waste into rivers and in any place need to be eradicated by consequently enforcing regulations applied in each environment. In the future, if the business is in need of going concern or being sustainable, the business waste shall be required not to still cause problems because if a space for the problem is opened and discussed en masse, it will endanger the sustainability of the garment business.

The gap to be filled with this research is the environmental accounting treatment in which it is desired that environmental protection is carried out in harmony without causing pollution on it. With the practice carried out by PT Quarzia Batik Bali, there must be a separate cost item issued by the entrepreneur on an ongoing basis so as to provide legitimacy or recognition to the community that the company operates while not putting aside the environmental sustainability. Thus, this current study aims to examine the environmental accounting treatment that has been applied by PT Quarzia Batik Bali and to determine the implementation of Green Accounting in supporting the business continuity of PT Quarzia Batik Bali.

\section{METHOD}

The type of data used in this study is the subject (self-report data) obtained from interviews with informants. The data sources of this research are secondary data and primary data collected from 
PT Quarzia Batik Bali. The reason for making use of the primary and secondary data is by using the primary data in the form of interviews with the garment manager, the essence of the problem being studied will soon be found and suggestions for overcoming it can immediately be offered to the garment manager. Meanwhile, secondary data are needed to provide accounting reports in financial reports; whether the financing issued by the company to address environmental impacts has been listed or not.

This research was conducted using an interpretive approach method. The use of an interpretive approach is grounded with these two facts: 1) understanding emerges through interactions with selected informants, 2) the way the informants provide information with experience in the field. In addition, the interpretive approach allows researchers to engage subjectively with the research participants. This approach focuses on the subjective nature of the social world and seeks to understand it from the conceptual framework of the object being studied. Research using this paradigm aims to understand the experiences, perspectives, and individual significances (Setiawan, 2013).

The analytical tool used in this research is an interpretive descriptive qualitative analysis tool, which is a tool for analyzing the information and data obtained by interpreting the data based on the perpetrator's perspective. Here, the researcher tries to interpret the phenomenon from the point of view of the actor based on their interpretation of a phenomenon. So, after determining categories, themes, and patterns, the meaning of the data is then searched for or interpreted. Systematically, the data processing and analysis method refers to three concurrent flows of analysis activities: data collection, data reduction, and drawing conclusions. The following presents the elaboration of the stages:

1. Researchers collected the required data through interviews, documentation and literature study.

2. The next stage is data reduction.

3. The last stage is conclusion drawing.

\section{RESULTS AND DISCUSSION}

It is an obligation for companies to take notice of the environment in order to obtain legitimacy from the community. In the interview conducted, the head of production department said that we have made various efforts to pay attention to the environment, and one of them is to make a contribution to support the activities in the banjar.

Such an interview result proves that the company has tried to gain legitimacy from the local community by striving for following the existing value system in the community. In line with what Januarti \& Apriyanti (2005) claimed, the company strives to ensure that stakeholders perceive their activities as legitimacy.

In the interview, the head of finance department stated:

"We actually have paid for the waste disposal so that ours does not produce pollution to the environment. Before draining it to the disposal, we have made a drain and a reservoir to treat the remaining washing water. We also use environmentally-friendly dyeing materials so that they can be easily absorbed by the earth."

Established on the results of the above interview, PT Quarzia Batik Bali has issued special fees for the environmental protection. The company is aware of the impact of the its production activities that produce waste which can have an impact on environmental pollution. However, the disclosure has not been recorded or is still put together with other company activity costs, or the accounting department still uses conventional accounting which has not accommodated the activities that have been carried out on the environment and has not written them down in the financial statements. The success of a company is determined by three factors, namely quality, profitability, and environmental responsibility. The environmental cost report contains the information related to the relative distribution of environmental costs that is useful for improving and controlling the environmental performance (Hansen \& Mowen, 2009). 


\section{Green Accounting Application in Business Continuity}

The application of green accounting is required in a company as a disclosure. Environmental preservation will be achieved by incurring costs related to the environment. In the interview, the head of the production department said

"I have just heard about the green accounting, but we have done the issue of environmental expenses. The application of the green accounting will be truly supportive for the companies in disclosing the environmental problems they encounter, especially for our company which clearly, in its production, produces waste. Therefore, we should pay more attention to the environment and communities around the company environment."

Based on the interview above, PT Quarzia Batik Bali has been truly concerned about its environment. The application of environmental accounting is overly important in companies, especially regarding the allocation of environmental costs. This is in line with Sari (2013) says that industrial pollution and waste appear as negative instances of industrial operations. Industry requires an environmental accounting system as a means of controlling the corporate responsibility. The application of green accounting in a company, including PT Quarzia Batik Bali, is indispensable for the reporting process related to environmental costs incurred by the company with the aim of providing information about the environmental protection-based company's performance.

The green accounting acts as a means of reporting a company's operational activities related to environmental costs. This is in line with what the head of the finance department of PT Quarzia Batik Bali stated, as in the following:

"The application of green accounting is exceedingly supportive in the evaluation process, such as on environmental activities and in analysing, especially the problem of waste. This is because we took note of that this company produces waste. Environmental preservation cannot be done only once and for management funds have indeed been budgeted in company funds specifically for environmental management. The environmental activities that we carry out include the provision of waste facilities (special places), for example: building a pool of water used for immersion."

The transcript of the interview with the Head of Financial Department signifies that the application of green accounting is vastly supportive in the evaluation process, such as of the environmental activities. This is in accordance with the Government Regulations in the Law of the Republic of Indonesia No. 32 of 2009 concerning Protection and Management of the Environment. The application of environmental management represents the government guideline given to business entities producing waste in order to make efforts in the aspect of pollution and damage controlling to environmental functions which includes prevention, mitigation and recovery (Moedjanarko \& Frisko, 2013).

Through the application of green accounting, it is hoped that environmental sustainability is maintained, because implementing green accounting results in companies that will voluntarily obey government policies in the environment where the company operates. An adequate cost report provides a breakdown of environmental costs by category (Setiawan, 2013). According to (Hansen \& Mowen, 2009), environmental costs can be classified into four categories, such as:

\section{a. Environmental Prevention Cost}

Environmental prevention cost refers to the costs made for activities carried out to prevent the environment-damaging production of waste. The activities undertaken by PT Quarzia Batik Bali in preventing the production of waste realised through recycling the waste before it is distributed to the environment and installing a device to absorb the dyeing 
water. This is done in order that the waste will later be channeled into an environment free of harmful substances. This was expressed by the head of the production department in the following excerpt:

"In an effort to prevent environmental pollution, we made a separate pool together with recycling several times; then, the waste is diverted to disposal".

Through the quote from the statement, it can be seen that PT Quarzia Batik Bali has been very careful in anticipating pollution. In fact, after producing liquid waste, the waste is not immediately flowed to the waste storage place, but the dyeing water is refiltered in order that the waste is free from hazardous substances and is no longer colored so as not to disturb the beauty of the environment.

\section{b. Environmental Detection Cost}

Environmental detection costs refer to the costs required for activities carried out to determine whether the company's products, processes and activities have met the applicable environmental standards or not. Companies can follow environmental standards and procedures which include: (1) government regulations, (2) ISO 14001 (voluntary standards) developed by the International Standards Organization, and (3) environmental policies developed by management. In the interview with the head of production department it was said::

"We routinely carry out waste inspections and our company has an environmental document in the form of an Environmental Impact Analysis (EIA) which indicates that the waste we produce is not contaminated. We are judged directly from the prevention".

The statement in the interview reflected that PT Quarzia Batik Bali had been examined for its waste by an independent laboratory and as a result, no harmful waste was found. In making the efforts to address the environmental impacts, we first refer to the management and monitoring aspects contained in the EIA document.

\section{c. Environmental Internal Failure Cost}

These costs are the costs incurred for activities because the company produces waste. PT Quarzia Batik Bali made several recycled basins to catch dyes before they flow into the earth. In an interview with the head of the production department it was stated:

"We made use of environmentally-friendly dyes, but we are keeping our preventive preparation by making several recycling basins to ensure that our wastewater is no longer harmful to the environment".

Based on the excerpt in the above statement, it can be seen that after the production process and producing liquid waste, the waste is collected into a special pond. Then, everything is recycled so that the liquid waste is free from harmful substances. This liquid waste is collected in a special pool which is then channeled to disposal.

\section{d. Environmental External Failure Cost}

What is meant by environmental external failure costs is the cost of activities carried out after releasing waste or garbage into the environment. A company that are associated with carrying out their production activities and it is found that there is wasted waste exceeding the threshold, it is dealt with paying a fee. This was stated by the head of the production department in a statement: "Costs incurred in preventing environmental pollution for company activities were stated by the head of the finance department of PT Quarzia Batik Bali, as quoted in the following statement:

" The costs we spend in the process of environmental pollution prevention include 
the cost of purchasing lime. This lime is used to neutralize the liquid waste before it is returned to the earth. In addition, in the production process, pollution prevention is carried out before the waste is flown back into the earth. The costs we spend include the cost of making a stabilisation pond, the dam costs so that the water discharged to the disposal is colorless and unharmful to the environment".

The statement in the interview results above indicates that the efforts to prevent the environmental pollution by PT Quarzia Batik Bali are quite adequate; for example, in order to minimise waste which will later be disposed of to the earth, the resulting liquid waste has been recycled and neutralized with lime beforehand.

\section{Business Continuity in terms of Profit}

Every company will remain oriented to the search for economic benefits that allow them to continue to operate and develop; likewise, the PT Quarzia Batik Bali maintains its existence in supporting the business continuity by achieving maximum profit regardless of obligations such as incurring costs to the environment and helping the community around the company. In interviews with the head of accounting department, it is said:

"We always pay costs for the environment and to the communities around the company.".

Based on the interview transcript above, it implies that the company takes notice of the company's environment. According to Pratiwi (2013), so far companies have been considered as institutions being capable of providing a lot of benefits for the community, and therefore, companies have to maximise their profits in order to provide maximum contribution to society. To increase socially and environmentally responsible attitudes and to increase its accountability, companies should make social reports, the reports containing both narrative text regarding CSR activities and social costs.

\section{Green Accounting in Maintaining Environmental Sustainability}

The preceding efforts made to deal with environmental impacts carried out refer to the management and monitoring aspects contained in the company's EIA document. The environmental impact management is structured in a consciousness framework to reduce the use of available raw materials in the reuse of waste generated both internally and externally. In an interview with the head of the production department, it was stated:

"In the operation, the company always refers to the EIA document. In the document, it is explained that the waste we produce is no longer harmful and can be channeled directly into the earth"

The statement in the interview above shows that PT Quarzia Batik Bali has been trying to equalise the value system existing in society and the one existing in the company. By taking notice of this point, it will affect the survival of the company. Giving a good concern to environmental problems, a positive response from the local community and the market will influence decision making on environmental disclosures. The organisation tries to seek harmony between the social values inherent in its activities with the norms existing in the social system of society (Dowling and Pfeffer, 1975).

\section{Expectation with Green Accounting} Model to Support Business Continuity The production activities of PT Quarzia Batik Bali cause environmental costs. However, the costs associated with these activities have not been categorised 
according to environmental cost classification. The comparison between the costs of environmental prevention according to a theoretical perspective and those one related to environmental activities of PT Quarzia Batik Bali is shown in Table 1.

The factory classifies the costs according to the type of production waste it produces. This classification is not in accordance with the theory of Hansen \& Mowen (2009) because there are several environmental prevention costs according to Hansen and Mowen that are not found in PT Quarzia Batik Bali.

Table 1.

Environmental Activity Cost of PT Quarzia Batik Bali

According to Hansen and Mowen
1. Environmental prevention costs:
a. Evaluation and recovery costs of tools to
control pollution.
b. Cost of special designs and products to reduce
waste.
c. The cost of training and teaching employees to
study environmental impacts.
e. Environmental risk audit fees.
f. Environmental research implementation costs.
g. The conelopment costs obtaining an ISO 14001 certificate.

\section{Environmental detection costs:}
a. Environmental activity audit costs.
b. Product inspection costs with environmentally friendly processes.
c. The cost of developing environmental performance measures.
d. Costs of conducting pollution testing.
e. Environmental performance verification costs.
f. Pollution level measurement costs.

\section{Environmental internal failure costs:}
a. Equipment operation costs to reduce or eliminate pollution.
b. Management and disposal costs for toxic wastes.
c. Pollution equipment maintenance costs.

\section{PT Quarzia Batik Bali}

1. Environmental prevention costs:
a. Liquid waste installation (cost of making recycle tubs)
b. Dye neutralisation (lime) cost

\section{Environmental detection costs:}
a. The cost of obtaining an EIA certificate (that the company's waste is environmentally friendly).
b. Product inspection costs with environmentally friendly processes

3. Environmental internal failure costs:

a. Equipment operation costs to reduce or eliminate pollution.

b. Management and disposal costs for
toxic wastes.

\section{Environmental External Failure Costs:} Polluted rivers (lime) cleaning up cost

\section{Environmental External Failure Costs:}
a. Polluted lake or river cleaning up cost.
b. The cost of analysing the use of raw materials and energy efficiently.
c. Spilled oil cleaning cost. 
d. Contaminated soil cleaning up cost.

e. The cost of settling personal accident claims from environmentally unfriendly work practices

There are two types of environmental prevention costs at PT Quarzia Batik Bali, namely storage tank making cost and dye neutralisation cost. There are several costs that have not been budgeted for, such as the cost of training and mentoring for employees to be able to study the environmental impacts, environmental risk audit cost, field research implementation cost, environmental management system development cost and the cost of obtaining an ISO 14001 certificate.

There are only two types of costs for environmental detection at PT Quarzia Batik Bali, which are: the cost of obtaining an EIA certificate and the cost of examining products with an environmentally friendly process. Several types of costs that were not found include the environmental activity audit fee, the cost for environmental performance measure development, the cost for pollution test conduction, the cost for environmental cost verification, and the cost for pollution level measurement.

There are only two types of internal environmental failure costs at PT Quarzia Batik Bali, namely the cost of operating equipment to reduce or eliminate pollution and the cost of managing and disposing of toxic waste; there is no cost of maintaining pollution equipment.

In PT Quarzia Batik Bali's environmental failure detection cost, there is only polluted rivers cleaning up cost. The costs of failure to detect external environmental detection should also include the cost of cleaning the river, the cost of analysing the efficient use of raw materials, and the cost of cleaning up contaminated soil and the cost of settling personal accident claims from nonenvironmentally friendly work practices.

The various negative impacts that may be caused by company waste require a green accounting system as a control of company responsibility, because waste management by companies requires measurement, assessment, disclosure and waste management reporting costs from the results of company operations. Therefore, the implementation and disclosure of information on corporate environmental responsibility is something that the company should not override. Table 2 shows the environmental cost report formulations that PT Quarzia Batik Bali can use as a guide.

Table 2.

Environmental Cost Report Formulation of PT Quarzia Batik Bali

\begin{tabular}{|c|c|c|}
\hline No & Item Description & Cost amount \\
\hline \multirow[t]{9}{*}{1} & Environmental Costs & \\
\hline & $\begin{array}{l}\text { Pollution controlling equipment evaluation and } \\
\text { maintenance cost }\end{array}$ & $\mathrm{XXX}$ \\
\hline & Product costs for waste reduction & $\mathrm{XXX}$ \\
\hline & The cost of environmental impact studying training & XXX \\
\hline & Environmental risk audit fees & XXX \\
\hline & Field research implementation cost & XXX \\
\hline & Environmental management system development cost & XXX \\
\hline & The cost of obtaining a certificate & $\mathrm{XXX}$ \\
\hline & Total & XX \\
\hline \multirow[t]{4}{*}{2} & Environmental Detection Costs & \\
\hline & Environmental activity audit costs & XXX \\
\hline & Environmentally friendly product inspection fees & XXX \\
\hline & Performance measure development cost & XXX \\
\hline
\end{tabular}




\begin{tabular}{lll} 
& Pollution testing cost & $\mathrm{XXX}$ \\
& Environmental performance verification cost & $\mathrm{XXX}$ \\
Level measurement cost & $\mathrm{XXX}$ \\
& Total & $\mathrm{XX}$ \\
Environmental Internal Failure Costs & \\
Equipment operating cost for pollution reduction & $\mathrm{XXX}$ \\
Toxic waste disposal and management costs & $\mathrm{XXX}$ \\
Equipment maintenance cost & $\mathrm{XXX}$ \\
Total & $\mathrm{XX}$ \\
Environmental External Failure Costs & \\
Polluted rivers/lakes cleaning up cost & $\mathrm{XXX}$ \\
Cost of inefficient raw material use & $\mathrm{XXX}$ \\
Spilled oil cleaning cost & $\mathrm{XXX}$ \\
Contaminated soil cleaning cost & $\mathrm{XXX}$ \\
Cost of environmentally unfriendly work accidents & $\mathrm{XXX}$ \\
& Total & $\mathrm{XX}$ \\
\hline
\end{tabular}

Based on table 2, it is expected that the environmental costs of PT Quarzia Batik Bali are recorded based on the classification category. The measurement of a company's environmental performance should be based on the environmental activities that the company carries out during the productivity process by identifying environmental costs. This is supported by De beer and friend (2006) who claim that the disclosure of all costs related to the environment, both internal and external and the allocation of these costs based on their categories will have a good impact on the company's environmental performance. The implementation of green accounting at PT Quarzia Batik Bali will contribute positively to environmental performance and will support the sustainability of the business in the coming times.

\section{CONCLUSION}

PT Quarzia Batik Bali in an intense way has paid attention to its corporate environment. However, there are several types of expenses that have not been made such as: expenses for waste analysis and training of employees in handling waste. Through the application of green accounting, the company has been trying to reduce environmental pollution by taking into account the waste generated by the company's activities. Green accounting as an innovation in reducing environmental pollution is very helpful for the company in regard to the surrounding environment.

A company incurs costs in dealing with environmental preservation, but PT Quarzia Batik Bali's treatment of environmental costs turns it has not been classified based on its category. Environmental costs must be reported separately. In fact, PT Quarzia Batik Bali still classifies it with other costs so that these environmental costs are not visible in the financial statements. As a result, these environmental costs are hidden. This is because the company classifies these costs based on their activities. The unclear environmental cost classification leads the stakeholders to encounter difficulties in identifying the environmental costs incurred by the company concerned. PT Quarzia Batik Bali has not fully implemented the green accounting in terms of identifying, recognising, measuring, and disclosing the environmental costs regarding waste management.

The application of green accounting helps companies disclose the environmental problems they encounter. The application of green accounting fully helps the companies in the reporting process related to costs incurred in environmental preservation as an effort to prevent environmental pollution due to waste generated from the company's activities. In addition, the application of green accounting really supports the evaluation process such as environmental activities. Implementing green accounting for companies requires them to 
voluntarily comply with the policies of the government in which the company operates. Publication of appropriate environmental costs reporting will serve as a tool for the organisation (company) to fulfill the company's environmental responsibility for its accountability to stakeholders.

Indirectly, green accounting also serves as a means to evaluate environmental conservation and to improve the efficiency of environmental management to support business continuity in the present and in the future. The application of environmental management represents the government guideline given to waste-producing business entities in order to make efforts in the aspect of controlling pollution and damage to environmental functions which include prevention, mitigation and recovery, which will later support the business sustainability.

\section{REFERENCES}

Abdullah, M. W., Muchlis, S., \& Sari, S. N. (2015). Pengaruh Tekanan Stakeholders dan Tanggung Jawab Sosial terhadap Penerapan Akuntansi Lingkungan di Kawasan Industri Makassar. Assets, 5(1), 105-114.

Andayani, \& Riduwan, A. (2011). Tanggung Jawab Lingkungan dan Peran Informasi Lingkungan dalam Pengambilan Keputusan Manajemen: Studi Kualitatif. In Simposium Nasional Akuntansi. Aceh.

Bebbington, J. (2001). Sustainable Development: A Review of the International Development,
Business and Accounting Literature. Accounting Forum, 25(2), 128-157.

Burhany, D. I. (2011). Pengaruh Implementasi Akuntansi Lingkungan terhadap Kinerja Lingkungan dan Pengungkapan Informasi Lingkungan serta Dampakanya terhadap KInerja Perusahaan. Indonesian Journal of Economic and Business, 1(2), 1-8.

Hansen, D. R., \& Mowen, M. M. (2009). Cornerstones of Cost Management. Canada: Cengage Learning.

Januarti, I., \& Apriyanti, D. (2005). Pengaruh Tanggung Jawab Sosial Perusahaan terhadap Kinerja Keuangan. Jurnal MAKSI, 5(2), 227243.

Moedjanarko, E. C., \& Frisko, D. (2013). Pengelolaan Biaya Lingkungan dalam Upaya Minimalisasi Limbah PT Wonosari Jaya Surabaya. Calypatra: Jurnal Ilmiah Mahasiswa Universitas Surabaya, 2(1), 1-13.

Pratiwi, W. M. (2013). Akuntansi Lingkungan Sebagai Strategi Pengelolaan dan Pengungkapan Tanggung Jawab Lingkungan pada Perusahaan Manufaktur. Jurnal Akuntansi AKUNESA, 2(1), 1-19.

Sari, A. G. (2013). Tinjauan tentang Pencemaran Lingkungan Hidup serta Ketentuan Pidananya dalam UU No. 32 tahun 2009 (UUPPLH). Jurnal Ilmiah Berkala Universitas Kadiri, 5362.

Setiawan, T. (2013). Penerapan Akuntansi Manajemen Lingkungan pada Dua Puluh Lima Perusahaan yang Terdaftar di Indeks Sri Kehati. Jurnal Akuntansi, 9(2), 110-129. 